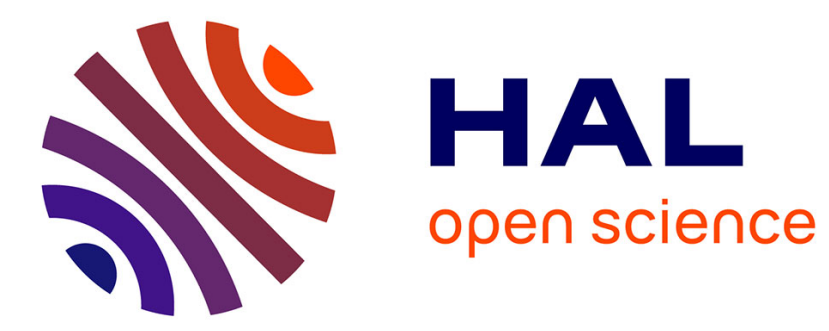

\title{
Hostile Witnesses, Judicial Interactions and Out-of-Court Narratives in a North Indian District Court \\ Daniela Berti
}

\section{- To cite this version:}

Daniela Berti. Hostile Witnesses, Judicial Interactions and Out-of-Court Narratives in a North Indian District Court. 2009. halshs-00413747v3

\section{HAL Id: halshs-00413747 https://shs.hal.science/halshs-00413747v3}

Preprint submitted on 27 Sep 2011

HAL is a multi-disciplinary open access archive for the deposit and dissemination of scientific research documents, whether they are published or not. The documents may come from teaching and research institutions in France or abroad, or from public or private research centers.
L'archive ouverte pluridisciplinaire HAL, est destinée au dépôt et à la diffusion de documents scientifiques de niveau recherche, publiés ou non, émanant des établissements d'enseignement et de recherche français ou étrangers, des laboratoires publics ou privés. 


\author{
Hostile Witnesses, Judicial Interactions \\ and Out-of-Court Narratives \\ in a North Indian District Court
}

Daniela Berti

This article aims to contrast a common opinion that people in India have a strong orientation to court compared to other forms of negotiation or advising (Galanter 1969, Foster 2007). In spite of the centrality of the court system to Indian public life, the flow of cases arriving at court may simply corresponds to a choice which the parties make in the first place, and which will eventually be abandoned in favour of private forms of compromise. By relying on the ethnography of a court case followed in a District court of Himachal Pradesh this contribution will show how even in serious criminal cases where no private compromise is allowed, it often happens that all the prosecutor witnesses deny before the judge what they are supposed to have previously stated to the police. The analyses of court's interactions and out of court narratives will show how non official forms of conciliation may internally unsettles the rules of evidence followed in criminal proceedings.

In a short article on the Indian legal system published by Foster (2007), an American Attorney at Law, he notes that with a million lawyers and 70,000 new lawyers each year, India boasts the world's second largest number of legal professionals after the United States. Further, in India, contrary to the United States, relatively few cases are settled outside the courtroom (Ibid.: 26) Forty years previously, in the introduction to a special issue of Law \& Society dedicated mostly to South Asia, Marc Galanter had observed that a specificity of Indian lawyers, in contrast to their American counterparts, was their strong orientation towards courts (compared to other legal settings) and their orientation towards litigation rather than advising, negotiating or planning. This orientation towards courts, Galanter wrote, 'is vividly displayed in spatial terms - lawyers are to be found literally at the court' (Galanter 1969: 27). Indeed, 'Judicial Court Complexes' in India are often the most animated parts of the towns where they are located, with an incessant coming and going of people, from other towns or distant villages.

However, in spite of the centrality of the court system-inherited from British common law- to Indian public life, the flow of cases arriving at court sometimes simply corresponds to a choice which the parties make in the first place, and which will eventually be abandoned in favour of other non official forms of compromise or adjustment. Even in serious criminal cases where the state acts as plaintiff and where no private compromise is allowed, it often 
happens that all the witnesses that the prosecutor calls to the court to prove his or her case deny or strongly tone down their previous statements once questioned by the judge.

The problem of what in common law terminology is called 'hostile witnesses' is a recurring one, and has provoked many reactions and discussions from judges, politicians, and press editorials, in an attempt to find the best measures to redress the problem. While highprofile and publicized trials where a witness has been suspected of being politically pressurized or bribed get much attention, in fact, this is a situation that judges or prosecutors of any small district town are very familiar with. In many such cases, the fact that prosecution witnesses turn hostile is not necessarily due to political pressure or to corruption but to various village or familial dynamics which influence the trial. In fact, even in criminal cases which are defined in the Indian Penal Code as non-compoundable so that no private compromise is allowed (cf. Baxi in this issue) the plaintiff as well as the witnesses who have initially testified against the accused, may decide to testify now in his or her favour.

While these forms of conciliation or compromise have frequently been documented by anthropologists working at a village level (Cohn 2001, Hayden 1999, Moore 1993), they have not yet been studied in the form they take at the very moment of the trial, in the courtroom. Even though the parties cannot disclose the compromise they have reached privately at a village or family level, at the trial this private compromise is used to deliver a public judicial acquittal. Even as it keeps intact the appearance of a legal trial, the private compromise internally unsettles the rules of evidence followed in criminal proceedings.

This article analyses this move from private compromise to public trial, and its impact on the judicial arena. I show how the witnesses' denial of their previous statement takes form inside the court, the verbal exchanges this corresponds to, and the kind of discourse it is associated with. This will lead me to spell out the roles that each participant -the judge, the prosecutor, the lawyers and witnesses- plays during the trial, to follow their verbal exchanges, and to see how these exchanges are transformed when they are recorded in written form, into what will become the official version of the trial. I will also compare the way in which the case is tried inside the court with the way it is understood or presented by the protagonists outside the courtroom (for a discussion of the 'ethnography of discourse' and speech acts in court rooms, see Conley and O'Barr (1990)

From a methodological point of view, choosing the court as the starting place for fieldwork has the disadvantage of familiarising the observer with a case only many months, and even years, after the events took place - in other words, the time it takes the case to reach the court. Consequently, all the negotiations or compromises that have occurred at family or village level are no longer accessible to the observer - except in the form of a narration given by the protagonists to the conflict.. Thus, my focus here is not so much to understand what really happened within the village or family prior to the court hearing, but to analyse how village or family dynamics are played out inside the courtroom and how they actually influence the trial proceedings. This is an important point to be underlined. Indeed, what has so far been overlooked is that the court itself is a site where a dispute may be resolved informally, but with the trappings of formal procedure. 


\section{Facts into sections}

The case was opened by the State of Himachal Pradesh represented by the Public Prosecutor, against Gudu, ${ }^{1}$ a forty-year-old man from a village in Mandi district. After the death of his first wife, Gudu had married a twenty year old girl, Kaushlya, with whom he had two sons. In December 2004, Kaushlya was found hanging from a tree in the forest surrounding her village. The police was called in and an FIR (First Information Report) was recorded against Gudu, on the request of the girl's mother, Saro Devi and the girl's paternal uncle, Buddhu Ram, a retired policeman. Buddhu Ram's daughter was married to the brother of the accused, making the relationship between the two families especially strong.

The FIR was registered under two sections of the Indian Criminal Code: section 498A 'punishment for subjecting a married woman to cruelty' which is punishable by 'three years' imprisonment and a fine' and under section 306, 'abetting the commission of suicide' whose punishment is '10 years' imprisonment and a fine'. These two sections are part of the measures taken in India to prevent so-called 'dowry deaths', i.e. deaths of married women who have been harassed by their husbands or in-laws by incessant demands for dowry. In order to prevent such abuse and under pressure from a large number of legislators and women's associations, dowry was (officially) forbidden according to the Dowry Prohibition Act of 1961. Following on from this Act (which did little to alter former usages), a series of amendments have been enacted, ${ }^{2}$ such as Section 113 A of the Indian Evidence Act, where 'the Court may presume, having regard to all the other circumstances of the case, that such suicide had been abetted by her husband or by such relative of her husband' (on the dowry provisions, see Menski 1998 and Palkar 2003). As a consequence of these measures, whenever a young married woman commits suicide, her husband and in-laws are immediately suspected and, upon the slightest accusation, arrested. ${ }^{3}$

When Kaushlya died in September 2004, Gudu, who was accused by the girl's mother of being responsible for what had happened, was immediately arrested by the police. After a period of three weeks imprisonment he was bailed out until the beginning of the trial, which started in October 2006 in a Session Court in Mandi district, in Himachal Pradesh and ended in June 2007 with an acquittal. The case was tried in the court of Judge A.D., who gave me permission to sit right next to the witness bar and the stenographer. I will start by analysing some passages of the trial interactions before considering the way in which the case was presented by the protagonists outside the courtroom.

\footnotetext{
${ }^{1}$ The names of the participants in the trial have been modified to protect their anonymity.

2 The amendments include section 498-A, which has been added to the Criminal Law (Second Amendment) Act, 1983; section 198-A of the Code of Criminal Procedure 1973, and section 113-A of the Indian Evidence Act.

${ }^{3}$ This threat of arrest has led to a number of newspaper articles which denounce what is called the misuse of the dowry provisions. See for example, Indian Dowry Law (209a): Myth Vs. Reality. An Investigative Report http://www.498a.org/contents/Publicity/498aBooklet.pdf
} 
In order to be able to follow the interactions that took place at the trial it is important to start with the allegation made by the girl's mother, Saro Devi, against her son-in-law Gudu on the day of the girl's death. The allegation, dated 10-12-2004, was written in Hindi by the police on Saro Devi's behalf, and signed by her at the police station. Here is one passage from the document:

I [Saro Devi] married my daughter Kaushlya Devi with Gudu on 9-10-2000 according to the Hindu ritual. We gave the dowry to our daughter according to our position. My daughter had a daughter and a son. My son-in-law Gudu used to beat her when he drank wine and his brothers also beat her. I met my daughter yesterday and she was alright and today, 10-12-04, at almost 1 o'clock Darshan Ram told me that my daughter Kaushlya Devi committed suicide by putting a rope around her neck and hanging herself from a tree. I have doubts about my son-in-law, Gudu, concerning the death of my daughter Kaushlya Devi. She got tired of his beatings and put the rope around her neck and finished her life. (my translation)

We will see how this allegation will be denied during the trial not only by the girl's mother but by all the other prosecution witnesses who had given a similar version to the police, at the time of the events.

In the following pages my aim is not to address the subject of dowry deaths, or to discuss the pertinence of the measures taken by the law to prevent and punish this kind of crime (on this, see Menski 1998). We will see that, given the direction the trial took, the hypothesis of a dowry death was immediately abandoned, the question being rather whether the girl was maltreated by her husband. I will move now to analyse the interactions between the protagonists during the trial.

\section{Testing witnesses}

In consonance with Indian proceedings, the State (in this case the regional state of Himachal Pradesh) was the plaintiff party, while eleven other people were prosecution witnesses. The defence chose to present no one.

On the first day of the trial, with the file lying before him, the Judge waited for the witnesses to appear before the bar. They had to notify their presence, then go out again and wait their turn outside. The first witness on the list was Saro Devi, the mother of the girl who committed suicide. However, before ushering her in, the judge called the pradhan (the president of the village council in the accused, Gudu's, village) to the bar for some preliminary questions. The pradhan, a woman in her forties, was also scheduled as prosecution witness on the same day. This interaction was considered to be 'confidential' and was not therefore recorded by the transcriber.

During this informal interaction, the judge reminded the pradhan of her statement at the time of the investigation that the reason for Kaushlya's suicide was that her husband had been harassing her for a long time. This preliminary questioning shows the judge's intention 'to test' the witness's attitude in order to understand whether such an important witness from the prosecutor's side maintained her accusation regarding the accused, and thus to what extent the 
prosecutor would be able to prove the accusations. In fact, as the judge explained to me in other occasions, given the pradhan's role of mediator in the village, the attitude he adopts before the court might enable the judge to evaluate what other villagers would do. Here are some passages from these interactions, translated from Hindi by me. In some cases, when the judge or the prosecutor used the English (thus without being understood by the pradhan) I will indicate it in the text.

Judge to the pradhan: It is written here [in the police report] that she [Kaushlya, the girl who committed suicide] was extremely troubled.

Prosecutor, cutting in and quite harshly to the pradhan: Speak now!

Judge, more kindly: Speak clearly, ok?

Pradhan, in a firm tone of voice: Nobody troubled her.

Judge, ironically, and without looking at the woman: Ha! There you go...

The judge's comment on the witness's reply caused the lawyers, who had moved nearer to the bench to follow the interactions more closely, to laugh out loud. The judge (as well as the lawyers) had indeed already grasped the situation: the village president had become 'hostile', which would question the possibility of the other witnesses maintaining their accusation. This was then explicitly stated by the prosecutor who commented: 'If the village president does that (tells a lie), the others will do the same! ${ }^{4}$

Pradhan: I am telling the truth.

Prosecutor: Then tell us, why you didn't say [as you said in your statement] that he [the accused] was doing something wrong?

Judge, cutting in and addressing the prosecutor: Why has the case been made then? (Then addressing the pradhan): Prior to this, did anyone also [in the village] hang themselves?

Pradhan, calmly: She did not hang herself.

Judge: What? How did she die then?

Pradhan: When we arrived there [at the place where the dead body was found] she had fallen down and her shawl and sickle were on the ground.

Prosecutor, cutting in and ironically: Of course, the forest is always a very dangerous place! (Lawyers laugh)

Though the judge had so far thought that the woman's suicide would not be questioned, he soon realized that this was in fact not the case: the village president not only denied what she had previously declared (about the woman being harassed) but she also firmly denied that the

\footnotetext{
${ }^{4}$ The fact that the village president's attitude may be indicative of what the other witnesses will say at the trial is frequently noted by authors writing about the relationship between the panchayat and the court (see for example Moore 1993: 85). This shows how, though the pradhan is now deprived of a judicial role, he/she is a crucial protagonist as regards the relations villagers have with the court and he/she is a regular witness in the court. His/her attitude plays a crucial role in the version that the other witnesses will adopt before the court.
} 
case had anything to do with a suicide. Another version of the events then emerged, that of an accident.

Prosecutor, rudely in English to the judge: She is not telling the truth!

Pradhan: Nobody there [at the place where the dead body was found] said that she had hanged herself.

Judge, quietly: We are not talking about phansi (hanging), we are just asking how she died?

While the prosecutor assumed an aggressive and sarcastic tone vis-à-vis the witness, the judge preferred to allow the woman the chance to present her own version of the facts. This happened quite frequently in Judge A.D.'s court and may be explained, at least partly, by the different roles the prosecutor and judge play during the trial. The prosecutor, who is directly responsible for proving the case, appears to be particularly concerned with a 'search for proof/evidence', whereas the judge appears more concerned with a 'truth' (Gibbons et al.,2004.: 46). Yet the different attitudes the judge and the prosecutor adopted towards the witness may also be partly explained by their different personalities. A.D., scrupulous, attentive, extremely self-confident and always keen to be entertained in legal discussions, contrasted with the personality of the prosecutor, a simpler man rather brusque with witnesses, especially those not responding as he would have liked.

The judge pursued the interaction by asking the woman to tell him about the place where Kaushlya's dead body had been found. He wanted to know whether the forest where the woman had been found came within the area of her panchayat.

Judge: Is the place (where Kaushilya went) close to your place?

Pradhan: It is very far from our house.

Prosecutor, very harshly: No, their house (of Kaushlya) is in her panchayat and panchayat people know this.

Pradhan, insisting and cutting in: Panchayat people do not go to other houses...

Prosecutor, cutting in: As a panchayat president it is your duty to know what happens in other houses.

Pradhan: Panchayat people do not know what anyone is doing at home.

Prosecutor: You had to gather information about this.

The Prosecutor was trying to make the pradhan feeling responsible for what had happened by implying that since the pradhan's house was very close to the place where the girl lived she should have known whether she was maltreated by her husband. But the pradhan, who showed great self-control, readily defended herself and denied what the Prosecutor was defining as a 'panchayat duty'. The judge then cut in by asking a question which implicitly accused the woman of lying.

Judge: Perhaps they [Gudu and his family] backed you in the elections?

Pradhan: What, sir?

Judge: Perhaps they backed you in the elections? 
Pradhan: We did not pay any attention to this. We do not know of this, and who will say 'I supported you in the election'?

Judge: Today everyone says that they supported [the pradhan, in order to obtain something from her/him]. Today they are very clever.

Pradhan: They didn't do that.

By evoking in court what the reason might be for a pradhan to testify in favour of one villager, the judge was trying to give a political explanation to a criminal case which had, in principle, nothing to do with politics. However, reference to political interest, is systematically made in case of a pradhan turning hostile. Besides, the reason why the pradhan had been called to testify in the court was not because she was an eyewitness (in fact she reached the victim much later than other villagers) but because she was the pradhan of the place.

Judge: I know you didn't see anything. You went there [to the place where the events took place] very late. What was the situation there? Whose fault was it? Those nearby said something and their family members also said something. ${ }^{5}$

Pradhan: Her family members are very simple. They do not know anything.

Prosecutor, ironically: Well, did she die or not? (Other lawyers laugh)

Pradhan: Yes, she died.

Prosecutor: Then how did she die?

The pradhan began to describe what people said after the body had been found. She said she had heard that the girl had gone to a marriage the day before and on the day of her death, went to collect grass in the forest and while cutting grass on a tree, she fell down and died.

Prosecutor, addressing the judge: No, no sir, it's a case of hanging! By falling from the tree she cannot end up hanging there.

Judge, referring to me: You see this foreigner there. She's going to see how much Indian women lie.

This was his implicit way of accusing her of telling a lie but the lady remained unperturbed. The defence lawyer, who had followed the interactions without saying a word, intervened here for the first time to support the woman's version: 'She fell from the tree. She'd hanged that bag for grass in the tree and it got stuck in the branches. The rope of the bag came up round her neck and suffocated her'.

The judge, without seeming to react to the lawyer's intervention, added a comment addressed to the pradhan: 'In this kind of case they [villagers] should ostracise [the accused]', inferring that the pradhan was expressing, for one reason or another, her support for the accused. Prosecutor, cutting in: If somebody does something wrong in a village, it is up to the panchayat to know who did the wrong.

\footnotetext{
${ }^{5}$ The judge himself was asking the witness to report 'hearsay', which is rejected in a courtroom (see also Conley and O'Barr, 1990:15).
} 
Then all speaking at the same time:

Pradhan: But we don't know.

Judge: Yes, but try to find out. As for the rest, living and dying, it is in the hands of god. Defence lawyer: But now she is no longer the village president.

Prosecutor: Yes, now there is another lady president.

Judge to the pradhan: Really? Then I would like to see that lady [the new pradhan] and I want to tell her that this should never happen again [case of hanging]. Ladies can't do this. They have no right to do this.

Here the judge, by referring to the frequency of women's suicides, expresses his feeling that the problem could not be solved simply through the law, but by solving the case at the local level. This interaction also shows the kind of 'turn-taking' (Drew and Atkinson 1979) that operates in the courtroom whereby, especially when the witness starts to turn hostile, the prosecutor, the judge, and the lawyer may all ask questions at the same time - what is the sign of a certain confusion.

After this informal and preliminary interview the judge asked the pradhan to wait outside the courtroom for the official hearing. Then, he proceeded to collect the evidence of Saro Devi, Kaushlya Devi’s mother.

\section{Oral versus written}

We have seen how the judge, before officially starting to collect the evidence, questioned the village pradhan as a sort of barometer indicating the direction the trial was to take. This questioning, though held in public, was not recorded in writing. Furthermore, it was not heard by the other witnesses, who were sitting outside the courtroom, waiting to be called. By contrast, with the arrival at the bar of the girl's mother, Saro Devi (who the record gave as the first Prosecutor Witness, PW 1) the interactions began to be recorded. Some passages of Saro Devi's evidence will be used here to show how the witnesses' oral statements during the spoken evidence are reformulated to be recorded in a written report. ${ }^{6}$

Saro Devi was a village woman in her forties. Her husband was not at the court since he was mentally retarded as a consequence of a disease he had some years before. The judge started to ask her some preliminary questions:

Judge, in Hindi: After marriage, where did your daughter live? Does she have children?

Saro Devi: Yes, there are children.

\footnotetext{
${ }^{6}$ While most of the witnesses speak Hindi or Pahari (the local language), their statements are immediately translated into English and reworded in a judicial language. Most of the time it is the judge who translates the witness's words, yet the prosecutor and the defence can also do this. During the cross-examination there may even be some tension as to who should first dictate the translation to the transcriber, so that it is worded in the most appropriate manner. Secondly, the reason why the witness's oral reply is transformed when drafted in its written version is that what is orally a reply to a question is dictated by the judge to the transcriber in the form of a statement made by the witness in the first person -as a sort of personal narration.
} 
Prosecutor: One daughter and one son.

Judge, dictating in English: After marriage my daughter gave birth to a son and daughter.

Judge, in Hindi: Where are they now?

Saro Devi: At home.

Judge: At your house or his [father's] house?

Saro Devi: They are at their [father's] house

Judge, dictating in English: ... who are in custody of the accused.

This is an important point in favour of the accused. Indeed, if there were no sons, there could have been more reason for harassment. The Prosecutor then intervened by asking, 'after marriage did she use to come to your house?'. 'Yes sir.' the lady replied. This is also one of the first questions asked in this kind of case. In fact, if a married woman does not visit the natal home, always in a village other than her husband's, it is a sign that her in-laws and her husband blackmail her for dowry.

After some more questioning, where the woman did not reveal any problems her daughter was having with Gudu and his family, she eventually said in vague terms that, yes, a year ago her daughter had started complaining that her husband was beating her.

Judge: She did not say why he (Gudu) beat her?

Saro Devi: No.

The judge insisted on getting the woman to repeat the accusation she had made when the case had been recorded by the police. However, two years had passed since her initial statement and the woman seemed now to hesitate in repeating her accusations.

Another point on which the prosecutor insisted during questioning was to find out since when Kaushlya had started complaining of being maltreated. The prosecutor's concern must be interpreted in relation to the section under which the case was tried. Under Section 113A of the Evidence Act, if a woman commits suicide 'within a period of seven years from the date of her marriage' the court may presume that the suicide had been abetted by her husband. To demonstrate his case, the prosecutor needed the woman to go back much further in the past. This would have shown that any maltreatment of Kaushlya was not due to sporadic misunderstanding between husband and wife, but was the outcome of a long-term attitude on the part of the husband. This would have given more substance to the hypothesis of a dowry issue.

However, every time the prosecutor asked Saro Devi to go back to the very beginning of her daughter's problem, the woman kept starting her narration from a very recent period - which she perceived, independent of any legal considerations, as the most relevant period if the cause of her daughter's death was to be understood. This shows how, as Conley and O'Barr note in reference to the Anglo-American system, 'the law of evidence is in one sense epistemological: it imposes on witnesses' accounts the law's view on what constitutes a fact and what sources of information are reliable' (Conley and O’Barr 1990:18). 
The prosecutor continued to question her and make her say something against the accused; that he maltreated his wife or harassed her often over the years. Eventually the judge interrupted him, saying in English, 'There is nothing in particular! She said that she (her daughter) did not complain about anything!'. The woman then said that, when the body was found, someone from the village called her and told her that her daughter had fallen from a tree. When she got there, she saw her daughter on the ground, who did not have any signs of strangulation on her neck. The prosecutor, looking astonished, said, 'But how did she die then?' To which the mother replied, 'Sometimes she was sick. I do not know.... Only god knows!'

The judge would not dictate this reply. Instead he dictated to the typist in English (thus without being understood by the witness) a sentence referring to the version that the woman had given in the police report: 'I have reasons to believe that my daughter was killed by the accused due to maltreatment. My statement Ext. PA was recorded by the police and bears my signature'. He then addressed the woman with an astonished smile, 'Your statement was written down at the time! It is a strange case!' The woman reacted by murmuring, 'There are two children. The children are young. They have to be looked after'. Although this last comment might have helped to explain why the woman did not confirm her previous written statement, it was not dictated by the judge to the transcriber either.

The judge also decided not to take into account what the woman had said just prior to this comment; that her daughter showed no sign of strangulation round her neck at the time of her death and that she could not give the exact reason for her death. These statements were very different from what she had said two years before, in her deposition. The contradiction between these two versions might have led the judge to declare the lady a 'hostile' witness. Instead, he decided to take into account the written report she had given the police two years before, rather than her current oral version. This decision shows a certain attenuation of the principle of orality followed in other adversarial systems where the judge, as well as the jury, "do not bear any procedural memory exceeding the trial hearing" (Scheffer 2007:14). ${ }^{1}$ By contrast, in Indian criminal trials, depositions previously signed by the witnesses in the presence of the police -though having no value as evidence as in other adversarial system-are frequently used during the trial by the judge himself, and sometimes shown to the witness at the moment of the trial. As will emerge from the rest of the hearings, this is not the usual procedure. We will see how, with other witnesses, priority will be given to their oral statements which will be recorded as evidence.

Saro Devi was then cross-examined by the defence lawyer. The lawyer insisted on one point that was essential for him to build his defence: he wanted the lady to say that her daughter frequently used to climb trees to cut leaves and that she carried a basket around the neck and the breast. He insisted on this point for quite a long time:

Defence lawyer: When you have to cut grass in narrow and sloping places, you have to carry grass bag here (around your neck and on the back). Don't you?

Lady: I don’t know...

The judge seemed puzzled and asked the lawyer: What is this? The lawyer insisted, certain of the customs in the region: 'When we have to take cuttings from a tree, we take a basket and 
we wind one part here [around the neck] and the other here [around the stomach]. Kaushlya's feet slipped on the tree and she found herself hanging from the branch because of the grass basket. She suffocated and died. This is all because of the basket'.

The judge tried to put an end to the discussion and dictated to the transcriber in English 'It is correct that a basket is fixed around the neck and the waist to pick grass and to collect leaves from a tree. I cannot say whether my daughter had fixed this basket in such a way on that particular day." (Court record).

Other points that the defense lawyer managed to get out of the witness were that she had registered the case against her son-in-law under pressure from Beli Ram, her husband's brother. When informed of Kaushlya's death, Beli Ram had immediately gone to the site where the body was found and, being a retired policeman himself, had given villagers instructions on the procedure to follow. The judge then dictated: "Beli Ram is my brother-inlaw who has retired from the Police Department. It is correct that I lodged the report with the police on the said Beli Ram's insistence.'

After reproaching the defence lawyer for his excessive and useless questions, the judge asked the woman to sign the written record of the evidence and told her to leave.

\section{Non binding statements}

The pradhan was again called to the bar, this time to officially record the evidence. Taking into account what had happened in the previous informal interaction, the judge went straight to the point:

Judge: When you got there, what did you see near the dead body?

Pradhan: Nothing! Only a shawl and a sickle (to cut the grass).

Judge: And the rope?

Pradhan: There was no rope there.

The prosecutor then murmured some words and the judge dictated:

Judge: At this stage learned PP states that the witness is partly suppressing the truth and that he should be allowed to cross-examine the witness. Request considered and allowed.

Here the judge, by speaking on behalf of the prosecutor, was asking and granting in a routine formula permission to cross-examine a witness whom he considered to have turned 'hostile'. ${ }^{7}$ In fact, by denying the existence of the rope near the dead body the pradhan was again denying what she was supposed to have stated to the police during investigation. After inquiring from the pradhan her level of study (a way of asking if she was literate), the judge showed her the deposition which she had signed: 'Look here, and then read that over there, at

\footnotetext{
${ }^{7}$ Normally the prosecutor does not cross-examine his or her own witnesses but since here the witness was no longer supporting the prosecutor's case, he could get the right to cross-examine by declaring her hostile.
} 
the beginning of the paper. When you signed here, it was all already written there. It is written in Hindi. Read! You are able to read Hindi, aren't you?'

But the pradhan replied calmly, 'It was not written there when I signed'. With this reply she was accusing the police of having added information (the presence of the rope) which was not there in the original document. The judge dictated in English:

I have not stated to the police that rope, shawl and sickle were sealed by the police in separate parcel in my presence (confronted with portion A to A of mark A where it is so recorded).

The Judge, showing signs of impatience, continued his enquiry by reading the report that the lady was supposed to have signed:

Judge, reading the file: She [Kaushilya Devi] had some marks here near her arms, and some signs of hanging.

Pradhan: No, it was not like that.

The judge, after dictating her reply addressed the lady:

Judge: Look, Pradhan ji, they [Gudu and his family] voted for you [in the panchayat elections] and in order to save him [Gudu] you are telling a lie.

Pradhan: No Sir, they did not back me and I am not telling a lie.

The judge formulated this last reply as follows: 'It is incorrect that I am suppressing the truth because the accused backed me at the election of pradhan'. Then he commented, 'Time is flying and witnesses are wasting time'. The prosecutor too made some last comments addressed to the woman, 'This is your panchayat and you are telling a lie and hiding things'.

Compared with Saro Devi's interrogation, we may note how differently the judge reacted faced with the witness's denial of her previous accusations. In this case the witness's oral statement was dictated by the judge to the transcriber, but a reference to the written report was also added (such as 'confronted with portion A to A of mark A where it is so recorded'). This mention is a technique commonly followed during the evidence record in order to indicate a contradiction between what the witness says in the courtroom and what is reported in the police report. Moreover, the pradhan was even more explicitly presented as a 'hostile witness'. This was done by the judge by using a specific cross-examination technique which consists of evoking a reason for the witness's change of stand and by dictating, on the witness's behalf, a standardized formula whose effect is to affirm the very contrary of what is being denied: 'It is incorrect that I am suppressing the truth because the accused backed me in the elections of pradhan'. Of course, neither the judge nor the prosecutor possessed any evidence to lead them to think that the accused could have put pressure on the pradhan concerning this specific case. They merely evoked the most logical reason for a pradhan to obstruct the prosecutor during the case. 
The pradhan's attitude before the judge made the defence lawyer's task of cross-examining her easy. What emerged in the cross-examination appeared to give even more basis to the defence effort to show that the police had fabricated the whole case against the accused. For example, the defence provided the pradhan with the possibility of pointing out that the sickle she saw near the body was not the same as the one in the police's possession which had been exhibited before the judge. He asked the lady to confirm that the sickle there in the courtroom was the kind for cutting grass, whereas the one actually found near Kaushlya Devi's body was the kind for cutting leaves from trees. The pradhan's confirmation that it was the latter type was a step forward in supporting the version that the girl slipped from the tree while she was cutting leaves.

\section{Mild accusations}

The medical witness who carried out the autopsy of the girl's body was then examined. She gave a lot of quite detailed description and confirmed orally what he had written in his postmortem report, that the cause of death was 'spinal cord compression due to hanging'.

The defence lawyer tried to find various ways of making the doctor admit the possibility that the marks found on the body could well be a consequence of the girl falling from the tree. Much discussion ensued about the size of the mark found around the neck - was it a large mark as in the case of a cloth, or was it small, as in the case of a rope? The defence lawyer insisted on defending the hypothesis of an accident and even tried to actually demonstrate it by winding a cloth around the doctor's neck to show how 'mechanically' one could be hanged by the kind of basket used for grass.

The doctor did not appear to support the lawyer's hypothesis, and the judge eventually insisted that the lawyer stop his cross-examination on this particular point: 'there is no way [to show this] it doesn't work!'

Other witnesses came to the bar. Although they were all called 'Prosecution Witnesses', none of them gave much support to the Prosecutor's case. At one point during the recording of evidence, the judge even lost his patience and, faced with yet another witness contradicting his previous statement, manifested his disappointment in Hindi: 'I don't want to write down his statement! It is the same [as previous witnesses]!

The only witness who somehow confirmed the accusation was the girl's uncle, Beli Ram, the retired policeman who had suggested that the girl's mother lodge an FIR against her sonin-law. Beli Ram told the judge that a year before Kaushlya's death, after she had once again complained of Gudu's maltreatment and beatings, he advised her husband to mend his ways. The accused then, Beli Ram added, 'apologised and assured that he would treat Kaushlya Devi properly'.

Reference to this request for forgiveness was not mentioned in the statement Beli Ram had given to the police upon Kaushlya's death and gave the judge to understand that even this important witness had eventually 'turned hostile'. Without even waiting for the prosecutor's reaction, the judge dictated to the transcriber the standardised formula commonly used in such a case: 'At this statement Learned Public Prosecutor stated that the witness is trying to suppress the truth, as such permission be granted to cross examine the witness. Prayer considered and allowed'. The Judge then resumed his questioning of Beli Ram: 
Judge (looking straight into Beli Ram's eyes): Are you telling the truth or are you lying? Beli Ram: I am telling the truth.

Judge: How did you give him advice [to tone down his behaviour]?

Beli Ram: I made suggestions to both of them [husband and wife]. Whenever they fought, I would go there and make suggestions. And then Gudu would ask for forgiveness.

Judge: What apologies did he make?

Beli Ram: He said "Please forgive me this time, I will not do it again”.

The judge appeared disappointed but somehow also resigned. Meanwhile the prosecutor continued to formulate some questions but Beli Ram's replies, although confirming some of his previous statements, were not convincing enough to support the accusations. What the judge later wrote in his report may clarify the point:

'This witness [Beli Ram] has also not given any date, month or year of beating or maltreatment and his statement qua maltreatment is vague and general in nature. In fact this witness was got declared hostile by the prosecution There is nothing in the statement of this witness as to when Kaushlya Devi met him lastly and told about her suffering to him. In such circumstance, much reliance cannot be placed on the testimony of this witness. (Judge's Order, Court record) ${ }^{8}$

It was now the defence lawyer's turn to cross-examine the witness:

Defence lawyer: It is like this - you persuaded Saro Devi [the girl's mother] to make a false case and to trap Gudu.

Beli Ram: No, it is not like that.

Defence lawyer: You said to the villagers present that, no one should move the body otherwise you will get them all arrested.

Beli Ram: No, it is not true!

The following appeared in the court record: 'It is incorrect that the accused has been framed in this case at my insistence. It is incorrect that I told the co-villagers of the accused not to touch the body of Kaushlya, otherwise they would be arrested.' The lawyer also evoked the idea that Beli Ram would have used his authority as an ex-policeman to scare villagers to let the police record a case against Gudu. Although he knew that both these ideas had been refused by the witness he wanted them to be written, at least under the negative form 'It is incorrect that...', in the court record.

\footnotetext{
${ }^{8}$ This is the original English as dictated by the judge to the transcriber.
} 
The arguments were made some days after concluding the recording of evidence, in the presence of the accused, with no other villagers present. The prosecutor who had presented the case was on leave. Anyway it was quite certain now that it was impossible to prove his case, since the witnesses had turned hostile. His place was taken by a prosecutor from a nearby court. He did not show much conviction concerning the case, and started to expose his arguments to the judge calmly:

Prosecutor, to the Judge: Sir, there are two pieces of evidence for Kaushlya's case. Saro Devi and Beli Ram are clearly saying that Kaushlya was maltreated by her husband, Gudu. I have also the post-mortem report of the doctor, and he says clearly that the signs in the neck were of rope so she had died because of suicide.

Judge, to the Prosecutor: But Saro Devi said (during the hearing) that her daughter was afraid of beating but she was not maltreated. (Then, looking at the evidence record): She said that he was supplying all necessary things to her.

Defence lawyer, to the Judge: Sir, it is not a case of suicide; Saro Devi said here that when she visited her daughter's house everything was fine there and the accused was providing her with everything, it was fine there. ...This sickle was not also the same, it contradicts [the previous statement]. The rope was not found there either while the prosecution said that a rope had been cut down.

Judge: But the doctor said she couldn't slip the way you are saying.

Defence lawyer: But she never complained about maltreatment.

Judge: Yes, the complaint of the parents is important in this matter, all others are not important.

During the arguments the judge showed quite a different attitude compared to the way he had behaved during the evidence, when he frequently accused witnesses of having told a lie. The general atmosphere of the court was also different during the arguments - compared to the passion and tension which appeared during the witnesses' interrogation. Here the discussion appeared much more technical, with the judge's role usually limited to that of a passive listener. As a matter of fact, due to the absence of a jury, ${ }^{9}$ the arguments here, unlike in an Anglo-American trial, do not assume a theatrical character; they take place during a tête-à-tête with the judge.

The arguments were pursued, with the defence lawyer reading line after line of recorded evidence. The lawyer repeatedly argued that Kaushlya had not committed suicide. He contended that if there had been a fight with her husband the day prior to the events, her body would have some sign of this maltreatment, or her bindi (mark on forehead) and sindhoor (coloured hair powder in parting) would at least have been removed. And even if there had been no fight and she had wanted to commit suicide why -the lawyer argued- would she have

\footnotetext{
${ }^{9}$ The jury system has been abolished in trial courts since 1960 .
} 
bothered adorning her body? He said, 'she would have been angry, why would she have put sindhoor on her scalp?. She was happy and only God knows why she died’.

Judge: If a woman is unhappy, it does not mean that she won't use bindi and sindoor and she will become a widow.

Lawyer: But the abetment has not been proved, Sir.

Judge: Now give the introduction of the canon (law) so that you can explain...

The judge here asks the lawyer to show how he had built up his defence by relying on court precedents. The lawyer highlighted different decisions of the High Court to support his argument. One of those cited by the defence was state of H.P. Vrs Savinder Kumar HLJ/174, 2004 for the legal definition of 'cruelity' - "that mere beating by the accused would not constitute offence"; or the explanation attached to section 498-A, where the conduct of the offender "should be of such nature as is likely to drive the woman to commit suicide". But in the absence of cruelty, the benefit of the doubt goes to the accused. The lawyer went on quoting previous judgements and at the end, the judge closed the arguments by concluding 'This is right'.

In his order the judge came back to the problem of 'death for dowry' treated by the two sections concerned by the case. Here is a passage from the English original version:

No doubt there is an alarming increase in such like cases which are frequently coming before the courts. Such crimes are generally committed in complete secrecy inside the house and it becomes very difficult for the prosecution to lead evidence. No member of the family, even if he is a witness of the crime, would come forward to depose against another family member. The neighbors, whose evidence may be of some assistance, are generally reluctant to depose in court. However, the prosecution is to prove such circumstances on the record which compelled the wife to commit suicide and such circumstances are missing in the case in hand. (Court Record)

While the judge, as it would appear in the report, made reference to the reticence of the girl's mother or of the other family members to testify against the accused, the defense lawyer's version was different. What the lawyer chose to show was that the story of the suicide had been entirely invented by the members of the family, under pressure from Beli Ram. The hypothesis that the lawyer had tried to demonstrate during the trial was that of an accident - an idea which had also been supported by some prosecution witnesses, who had denied having seen a rope near the body. However, we will see how this hypothesis was just the version that the lawyer had chosen to present for his defense.

\section{IV}

\section{The non legal story of the death}

Speaking outside the court, the defense lawyer had no doubt that Kaushlya had committed suicide. However, the reason for the suicide had nothing to do with dowry problems. He reconstructed a scenario which he claimed had taken place the night before the girl's death 
when she went to attend a marriage in another village. I will give some details of his version in order to show the kind of narrative such suicide cases correspond to outside the courtroom.

I tried to find out what the truth is because, of course, this is a case of suicide - there is the photograph, the rope and it is a proved and admitted case. So, what inquiries did I make on my part? The truth is that the day before the suicide, Gudu wanted to go to a wedding which was celebrated near his village. He told his wife that she had to bring his clothes to the place where he was working and that he would go straight on from there. She was a stubborn and moody girl and she said, "You have to stay at home and look after the cattle and children. I will go on my own". So what did she do? She did not listen to him, and went with other villagers to that wedding and came back late at night. On the way back she was accompanied by other villagers, including some haughty boys from the village who had drunk some local liquor.

The lawyer continued with some personal comments, not only about what he thought to be the specific personality of the girl but also general considerations about women's condition in India:

Kaushlya Devi was a rather childish and short-tempered woman who was perhaps also unhappy with her husband. She was very pretty, extroverted and much younger than her husband and she flirted with some of the village boys. Gudu knew of the gossip, which was the reason why he sometimes abused his wife and hit her. This (continued the lawyer) does not mean 'cruelty' in the sense mentioned by article 498a of the Criminal Code (i.e. 'Punishment for subjecting a married woman to cruelty'). He was just hitting her a little bit. ... That girl was very loose. You saw her photo in the file. ... There were some young boys in the village who teased her. They sometime told him (Gudu), when having a drink together, that she was playing around with somebody else. At least some boy or other told him that. On that particular day, those boys were also with them (his wife and other people). Then he came back from work, tied up the cattle, looked after the children, cooked some food and after eating it went to sleep. She arrived home at night and as soon as she had entered his room, he became angry and slapped her ...shouting out that she was like a prostitute. 'You went with those bad boys. Get out of here!'. So at night time she stayed in the kitchen outside ....In the morning she took her sickle and, feeling perhaps a little guilty and desperate, she committed suicide. Village women can act this way because they are not educated and are mostly simple-minded. They are not very mature. Why? Because they got married at a very young age..... Most marriages are arranged and this unsettles a wife. Her consent is never required. As for their body language, the wife is sometimes beautiful and husband not. Due to this mismatch, there is no mutual affection.

This way of presenting the case is certainly a mixture of what the lawyer had been told by Gudu and his personal feelings on the subject. Part of the commentary, however, appears to be part of a standardized script-like version which is regularly used by lawyers in preparing their 
defense in such cases. For example the fact of describing a girl who commits suicide as 'short-tempered' is regularly evoked by the lawyer in similar cases - as if this would be a sufficient reason for a woman to commit suicide. Similarly, the scenario in which the husband, while drinking with other villagers, finds out about his wife's relationship with another man is also quite frequently evoked in village stories (see Berti 2001).

It is important to stress here that the lawyer's interpretation of the case emphasizes the psychological and sentimental reasons which might have led the girl to commit suicide. Nevertheless, all the psychological or personal factors taken into consideration by the lawyer in his understanding of the case were not mentioned at all during the arguments where the lawyer repeatedly defended the idea that Kaushlya's death was accidental. According to him, the idea of the accident was more plausible and easier to prove before the judge than what he considered to be 'the true history' (related to the problem between wife and husband). He said he had voluntarily decided to give up the point of the lady's eccentric character: 'I thought why raise a doubt? Because suicide is a crime' - he said.

The accused, with whom I talked out of the court, confirmed to me the version of the suicide:

"We had quarreled many times before, Once she also stabbed me [showing me the mark of a wound by a knife on his hand]. After quarreling she often used to go out for cutting grass but she always came back. When graha (planets) are not good then these things happen."

He told me that Beli Ram asked the mother to register the case against him because his daughter was married to his younger brother and he was scared that she would also commit suicide. He also told me that at the time of the events, villagers were reluctant to call the police and were ready to carry the body to the crematory ground. They had said, "Now she is dead and if we call the police, her husband will go to jail and who will take care of her kids? But when the daughter's uncle, Beli Ram, came to know what had happened he said: "Nobody touches the body or you will all go to prison”. Then Beli Ram called the police who, under his instructions and authority (he was an ex-policeman) made the case against him. Since then, however things had changed. The likelihood that he would spend ten years in prison and that his children would be left to fend for themselves, had convinced everybody that he should not be condemned.

"My uncle in law [Beli Ram] even said that you will get free and if you will get convicted I will be at fault [...] My mother-in-law also told me that she said before the court that you did not quarrel and you did not beat her and you gave everything to her. [...] My brother's wife also said once to her husband that sister-in-law [Kaushlya] is wrong and brother-in-law is a good man. Sister -in-law is very nice with me. She also uses to wash my children's clothes.

Gudu was sure that all the family members as well as other villagers were now ready to help him and that the judgment was going to be in his favor. He was happy about the idea that 
he was soon going to get a copy of the judgment which would allow him to finally get a permanent job (he was working on daily wages as a road construction laborer). He stressed the normality of his family relations with his mother-in-law whom he often visited with his children. "If I am sent to jail who will look after my children? - he repeated to me many times - My parents are old and poor. My father-in-law is mentally sick and my brother has already his own children".

The lawyer too was sure of the fact that the Kaushilya's family members, including Beli Ram, were now in favor of the accused and also mentioned some meetings that had taken place among the family members. The latter were likely to support the version of the accident (as he himself had suggested) and to deny before the judge that a rope had been found by the police at the place of the suicide. This was also a further reason to deny Kaushlya's suicide and try to defend the idea of an accident.

\section{$\mathbf{V}$ \\ Conclusion}

At the end of the trial one thing was clear, as the judge himself told me, that some negotiations had taken place over the two years between registration and trial, at village and family level. As we have seen, the defense lawyer referred to discussions held among relatives and village elders, which led to the conclusion that for the children's sake, it would be better if Gudu was acquitted.

The judge in his order did not refer to these family considerations, although he may have taken them into consideration in his final decision. However, in his 13 pages of judgement he radically attenuated the sometimes accusative tone with which he addressed the witnesses during the trial. He also made no reference to the fact that all along the trial he had kept denouncing the fact that the prosecution witnesses had turned hostile. After commenting on the seriousness of the so-called 'dowry deaths' he insisted on the necessity for such cases to be clearly proved by the prosecutor, which he recorded, had not been the case here. He finally justified his decision to acquit the accused based on the total lack of evidence on the part of the prosecution.

It should be noted that in the judge's report, court interactions and the arguments there is no attempt to understand why Kaushlya had decided to end her life. The only issue was whether the reason why she died was due to her husband's 'cruelty' and if the legal definition of 'cruelty' corresponded to the situation at hand. Similarly, all the psychological, sociological and personality-based explanations regarding the case that the defence lawyer had given me outside the courtroom were not evoked at all during the trial, with most witnesses now supporting the idea that Kaushlya's death was accidental following a fall from the tree.

Indeed, the case shows how the written version of the interactions and the text of the judgment, do not reveal the true dynamics of the case, the attitudes, the roles (prescribed or played) of the various participants. The details of a large number of important interactions which may have helped understand the case were not transcribed in the court documents or in the judge's order. The moment the judge started to translate the witness's sentence and to 
dictate it to the transcriber, he had already discerned the facts of the case (Rosen 1989). We have seen, for example, how the words of the girl's mother, 'The children are young. They have to be looked after' were not taken as 'recorded evidence' and was never evoked during the arguments or in the final order. The record of the interactions taking place during the trial indeed 'selects among [the voice of litigants] silencing some and transforming other to conform to legal categories and conventions' (Conley \& O'Barr 1990: 168). Consequently, what witnesses say before the judge is as important as what they say outside the court (Ibid.: 35), where what is presented through the grill of a penal section, discussed according to a procedural protocol and judged on the basis of evidence or of a precedent, takes the form of a life story that participants in the trial reformulate and redefine according to their own role in the trial and their respective point of view.

The case also shows how Indian court proceedings maintain the important common law principle according to which the initial recorded statement 'is not part of the evidence before the court'. By contrast, we have seen that at the time of the trial the interactions are carefully recorded, although adapted to a specific language and judiciary codification. If this recording of the oral statements guarantees the witnesses the power to confirm or deny what they are supposed to have said at the moment of the investigation, it certainly does not guarantee the prosecutor success in proving his case. In fact, similar to what Mckillop notes in general for adversarial systems, the Indian trial is 'something of a lottery [whose] outcomes are dependent upon many variables', (Mckillop 1997: 565) which lends the criminal justice system a high degree of unpredictability. The case presented here shows how one of the most important variables determining the outcome of the trial is that of 'hostile witnesses'. A case, which at the beginning relied on eleven 'prosecution witnesses', with no defense witnesses at all, ended up being impossible for the prosecutor to prove.

\section{Acknowledgements}

This article is part of the ANR program "Justice and Governance in India and South Asia" (http://just-india.net)

I would like to thank the anonymous readers and the editors of CIS for their useful comments and suggestions. My thanks go also to the MacMillan Center and especially to The South Asian Studies Council at Yale which provided me a congenial atmosphere for writing a first draft of this article.

\section{REFERENCES}

Atkinson John P. and Drew Paul. 1979. Order in court : the organization of verbal interaction in judicial settings. London: Macmillan.

Berti Daniela. (forthcoming). Trials, Witnesses and Local Stakes in a District Court of Himachal Pradesh (North India). In Joanna Pfaff \& Gérard Toffin (eds) Citizenship, Democracy, and Belonging in the Himalayas. Sage: New Delhi. 
Berti Daniela. 2001. La parole des dieux. Rituels de possession dans l'Himalaya indien. Paris: Paris: CNRS Editions.

Cohn, Bernard. 2001 [1959]. Some Notes on Law and Change in North India. In Bernard Cohn (ed) An Anthropologist among the Historians and Other Essays, 554-575. Delhi: Oxford University Press [1990].

Conley John M. and O’Barr Wiiliam M. 1990. Rules versus Relationships. The Ethnography of Legal Discourse. Chicago: University Of Chicago Press.

Foster, S. Elisabeth. 2007. Doing business in India. Introduction and update for lawyers. The California International Law Journal 15 (1): 26-29.

Galanter, Marc. 1969. Introduction. The Study of the Indian Legal Profession. Law \& Society Review. 3 (2/3) [Special Issue Devoted to Lawyers in Developing Societies with Particular Reference to India] : 201-218.

Galanter, Marc. 1983. The Radiating Effects of Courts. In Keith O. Boyum and Lynn. Mather (eds.). Empirical Theories about Courts, pp. 117-42. New York: Longmans. .

Gibbons, Prakasam, J. Tirumalesh V. Hemalatha Nagarajan. 2004 KV. Language in the law. New Delhi: Orient Longmans.

Hayden, Robert. 1984. Disputes and Arguments among Nomads: A Caste Council in India. Delhi: Oxford University Press.

Mckillop B. 1997. Anatomy of a French Murder Case. American Journal of Comparative Law 45 (3): 527-583.

Menski, Werner. 1998 Legal strategies for curbing the dowry problem. GEMS, 6: 97-149 South Asians and the Dowry Problem. [Special issue on South Asians and the Dowry Problem edited by Werner Menski].

Moore, Erin P. 1993. Gender, power, and legal pluralism: Rajasthan, India. American ethnologist. 20 (3): 522-542.

Palkar, Vineeta. 2003. Failing Gender Justice in Antri-Dowry Law. South Asia Research. 23 (2): 181-200.

Rosen Lawrence. 1989. The Anthropology of Justice. Law as Culture in Islamic Society. Cambridge: Cambridge University Press.

Scheffer Thomas, Hannken-Illjes, Kati, Kozin Alex. Bound to One's Own Words? Early Defenses and Their Binding Effects in Different Criminal Cases. Law \& Social Inquiry. 32 (I): 5-39.

\section{Internet}

Dowry Law (209a): Myth Vs. Reality. An Investigative Report

http://www.498a.org/contents/Publicity/498aBooklet.pdf 